\title{
What We Know About Wage Adjustment During the 2007-09 Recession and Its Aftermath
}

Marianna Kudlyak

I $\mathrm{n}$ standard economic models, unemployment and real wage growth are tightly connected, moving at nearly the same time in opposite directions (Daly and Hobijn 2014). Historically, however, the relationship between aggregate real wage growth and unemployment has been weak and, specifically, aggregate wage growth has remained flat during the 2007-09 recession and its aftermath while unemployment has exhibited substantial swings (Figure 1). This experience has led many observers, including some policymakers, to question whether the low real aggregate wage growth during the current recovery indicates a weak labor market beyond what is measured by the official unemployment rate.

The category "aggregate wage" summarizes wages of all employed workers, and thus aggregate wage growth reflects actual changes of workers' wages, changes in the composition of workers, and changes in the composition of jobs. Some of these changes are related to underlying structural trends in the economy while others constitute the economy's response to the business cycle shocks and are more indicative of cyclical resource utilization in the labor market. Consequently, it is important to look beyond the aggregate statistics to understand

Kudlyak is an economist at the Federal Reserve Bank of Richmond. The author thanks Miki Doan, Robert Hetzel, Pierre-Daniel Sarte, and John Weinberg for useful comments and suggestions. The views expressed here are those of the author and do not refl ect those of the Federal Reserve Bank of Richmond or the Federal Reserve System. E-mail: marianna.kudlyak@rich.frb.org.

DOI: http://doi.org/10.21144/eq1010302 


\section{Figure 1 Aggregate Real Wage Growth and Unemployment Rate}

A) Total Compensation, Production, and Costs, 1948-2015

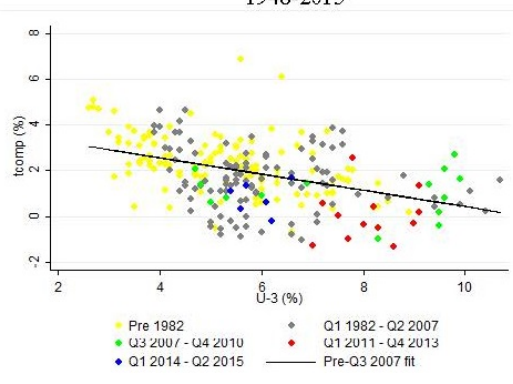

C) CPS Med Weekly Earnings, 1979-2015

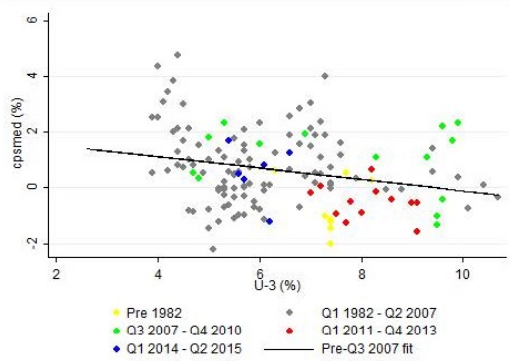

B) Average Hourly Earnings, 1964-2015

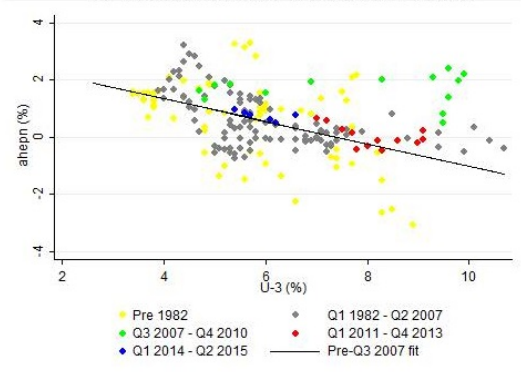

D) Employment Cost Index, 1982-2015

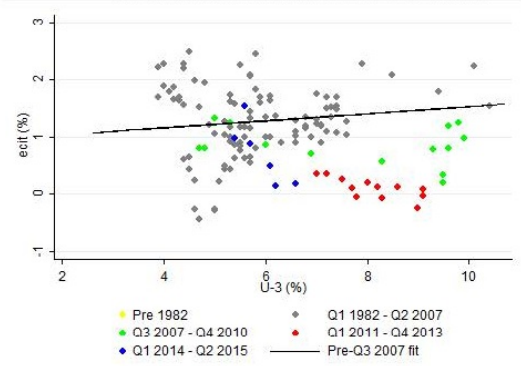

Notes: Each dot represents a quarterly observation on the unemployment rate and annual real wage growth. Hourly compensation in the nonfarm business sector is from the Bureau of Labor Statistics' Production and Costs tabulations. Average hourly earnings of production and non-supervisory workers are from the Current Employment Statistics. The employment cost index is from the National Compensation Survey. Median weekly earnings are from the Current Population Survey.

the behavior of real wages and its relation to the health of the labor market in the aftermath of the 2007-09 recession.

In this article, we review recent literature that studies the changes in the components of the aggregate wage over time and, specifically, after the 2007-09 recession. The review focuses on disaggregating the aggregate real wage growth into its changes due to: wage changes of workers who switch from one job to another, wage changes of workers who remain employed at the same job, wage changes of workers who move in and out of employment, and changes in respective shares of these groups. In principle, the change in the aggregate real wage from 
one period to another can be disaggregated along a few alternative dimensions - for example, the changes in the industry (or occupational) wages and industrial (or occupational) composition of employment, or the changes in wages of workers by sociodemographic characteristics and the educational and experience composition of the workforce. The decomposition in this article is motivated by the earlier (for example, Barro 1980) and recent macrolabor literatures that converge on a two-part argument regarding wage changes that influence job creation decisions of firms. First, wages of workers who do not change jobs do not directly influence the firms' job creation decisions. Instead, firms take into account the entire expected present value of wages to be paid to a newly hired worker (Haefke, Sonntag, and van Rens 2013; Kudlyak 2014; and Basu and House 2015). Second, wages of newly hired workers change much more over the business cycle than wages of workers who remain at the same job (see, for example, Bils 1985; Pissarides 2009; and Martins, Solon, and Thomas 2012), and thus movements in average wages are not the relevant statistics that influence firms' job creation decisions. Having disaggregated aggregate wage growth along the dimensions described above, we further examine the changes in the composition of each dimension along high- versus low-paying jobs and industrial or occupational makeup whenever the relevant studies are available.

Reviewing the literature, we find that wage changes of workers employed from one period to another are procyclical and the majority of the procyclicality is due to the wage changes of workers who change jobs from one period to another. The compositional changes in the aggregate wage are typically countercyclical. Consequently, aggregate real wage growth is procyclical but not in a statistically significant sense (Daly, Hobijn, and Wiles 2012). The review of the literature reveals that the aggregate wage growth in the aftermath of the 2007-09 recession is relatively low because of the relatively low contribution of the typically procyclical wage growth of job changers and because of the relatively large contribution of the typically countercyclical composition effect associated with transitions from part-time to full-time employment (Daly, Hobijn, and Wiles 2012). Despite the fact that the overall contribution of job changers to aggregate wage growth is relatively low in this recovery, the wage gains of workers who do switch jobs are high (Mustre-del-Rio 2014). In light of the recent literature on declining business dynamism (see, for example, Davis and Haltiwanger 2014), it may be that the relatively low rate of job-to-job switches is structural in nature.

Given the centrality of the question of wage growth for economic recovery, there have been a number of works studying wage growth 
in the aftermath of the 2007-09 recession. ${ }^{1}$ This article's intent is to provide a roadmap for readers of recent empirical works on wage dynamics in the context of wage changes as it relates to job creation decisions of the firms. ${ }^{2}$ The review is descriptive and many questions remain as to sources behind the weak growth of the components of the aggregate wage growth.

The article is structured as follows. Section 1 presents a framework for decomposition of aggregate wage growth into wage changes of workers who do not change jobs, wage changes of workers who switch jobs, wage changes of workers who transition between nonemployment and employment, and the changes in the respective shares of these groups. Section 2 summarizes Daly, Hobijn, and Wiles (2012), whose findings speak to the multiple components of the decomposition. Section 3 discusses evidence on wage adjustment of workers who do not change jobs. Section 4 discusses evidence on wage adjustment of workers who switch jobs. Section 5 discusses some evidence on wage adjustment of workers who transition from nonemployment to employment. Section 6 discusses the types of jobs workers transitioned to during the recovery from the 2007-09 recession. Finally, Section 7 concludes.

\section{A FRAMEWORK FOR DECOMPOSITION OF AGGREGATE WAGE GROWTH}

The change in real aggregate average wages between $t-1$ and $t$ can be decomposed such that it explicitly distinguishes between changes in the wages of job switchers and job stayers, relative wages of workers who enter and exit the workforce, and changes in the shares of each group of workers. Let $W_{t}$ denote the aggregate average wage in period $t$. Let $C$ denote the set of workers who remain at the same job from period $t-1$ to $t$. Let $S$ denote the set of workers who work in both periods but switch jobs between $t-1$ and $t$. Let $X$ denote the set of workers who exit employment between $t-1$ and $t$, i.e., those who are employed in $t-1$ and separated from employment in period $t$. Finally, let $N$ denote the set of workers who enter employment between $t-1$ and $t$, i.e., those who are unemployed or out of the labor force in period $t$ and employed in period $t-1$. Let $s_{i t}$ denote the share of workers in set $i$ of the workforce in period $t$. Let $w_{i t}$ denote the real wage of the

\footnotetext{
${ }^{1}$ As this article is being written, new works are published on the topic, and thus the review is necessarily incomplete. See, for example, Barrow and Faberman (2015).

${ }^{2}$ An interested reader is referred to a review in Kudlyak (2009) and a chapter in the forthcoming Handbook of Macroeconomics by Basu and Hause (2015) for the theoretical background.
} 
workers in set $i$ in period $t$. Then the aggregate wage change can be decomposed as follows: ${ }^{3}$

$$
\begin{aligned}
& W_{t}-W_{-1}=\sum_{i \in C, S, N} s_{i t} w_{i t}-\sum_{i \in C, S, X} s_{i t-1} w_{i t-1} \\
& =\sum_{i \in C} s_{i t-1}\left(w_{i t}-w_{i t-1}\right) \text { (1) wage growth effect of stayers } \\
& +\sum_{i \in S} s_{i t-1}\left(w_{i t}-w_{i t-1}\right)(2) \text { wage growth effect of changers } \\
& +\sum_{i \in N} s_{i t}\left(w_{i t}-W_{t-1}\right)(3) \text { composition effect of the entrants } \\
& \text { to employment }
\end{aligned}
$$

$-\sum_{i \in X} s_{i-1 t}\left(w_{i t-1}-W_{t-1}\right)$ (4) composition effect of the exiters from employment

$$
+\sum_{i \in C, S}\left(w_{i t-1}-W_{t-1}\right)\left(s_{i t}-s_{i t-1}\right)(5) \text { composition effect of }
$$

stayers and switchers

$+\sum_{i \in C, S}\left(w_{i t}-w_{i t-1}\right)\left(s_{i t}-s_{i t-1}\right)(6)$ composition effect from cross-term.

The first two terms on the right constitute the contribution to the change in the aggregate real wage from the changes of wages of job stayers and job changers, respectively, holding the shares of these groups in the pool of all employed constant at their period $t-1$ levels. The third term captures the effect of new entrants into employment: It

\footnotetext{
$W_{t-1} \sum_{i \in C, S}^{3}\left(s_{i t}-s_{i t-1}\right) s_{i t-1}, \sum_{i \in C, S} s_{i t-1} w_{i t}, \sum_{i \in C, S} w_{i t-1}\left(s_{i t}-s_{i t-1}\right)$
the left-hand side and note that $W_{t-1} \sum_{i \in C, S}\left(s_{i t}-s_{i t-1}\right) s_{i t-1}$

$W_{t-1}\left(\sum_{i \in N} s_{i t} w_{i t}-\sum_{i \in X} s_{i t-1} w_{i t-1}\right)$. After rearranging, equation (1) follows. Note that $s_{C t}+s_{S t}+s_{N t}=1$.
} 
captures the new entrants' wage relative to the initial aggregate wage weighted by their share in period $t$. The fourth term captures the effect of workers who exit employment: It captures the exiting workers' wages relative to the initial aggregate average wage weighted by their share in period $t$. Daly, Hobijn, and Wiles (2012), for example, find that the workers who transition from employment to unemployment usually come from the low end of the wage distribution and workers who enter employment from nonemployment usually enter at even lower wages. The fifth term reflects the changing shares of job stayers and job changers, weighted by deviation of their initial wages from the initial aggregate wage. That is, if the shares shifted toward the groups with higher wages than the initial average, such a shift would represent a positive contribution to the change in the aggregate real wage. Finally, the sixth term captures the remaining cross-term.

Movements in any of these components affect movements in the aggregate wage. In particular, a large literature documents that real wages of job stayers are weakly procyclical and the wages of job changers are highly procyclical (Pissarides 2009). ${ }^{4}$ Consequently, effects (1) and (2) should lead to procyclical aggregate wage changes. However, layoffs and hiring are not randomly distributed over the business cycle: Low-wage workers are more likely to be displaced in recessions and thus a measure of the aggregate wage gives more weight to low-skill workers in expansions than in contractions (Solon, Barsky, and Parker 1994). These composition effects might counteract the procyclicality of the wage changes of job stayers or job changers.

Note that wage changes of, for example, job changers can be due to the "true" wage change of workers who switch jobs (i.e., workers receiving higher pay for the same type of job) and/or due to a change in the types of jobs the workers switch to. The same applies to the effects of job stayers or the effects of workers transitioning from nonemployment to employment or vice versa. In particular, McLaughlin and Bils (2001) and Moscarini and Postel-Vinay (2014), among others, document substantial cyclical upgrading; that is, during economic recoveries workers switch to better-paying industries, occupations, or firms. To our knowledge, however, the evidence that explicitly distinguishes between such job-related compositional effects is scarce.

The decomposition above is analogous to the shift-share decomposition for productivity growth presented in Foster, Haltiwanger, and Krizan (2001) and is a simplified version of the aggregate median wage

\footnotetext{
4 A relative weak procyclicality of job stayers' wages can be rationalized by efficiency wage models, implicit contracts, or insider-outsider models.
} 
decomposition developed by Daly, Hobijn, and Wiles (2012), which is discussed in Section 2.

The next sections discuss recent empirical evidence on wage adjustment in the 2007-09 recession and its recovery in the context of the decomposition presented in equation (1).

\section{EMPIRICAL EVIDENCE ON THE WAGE GROWTH EFFECT AND THE COMPOSITION EFFECT FROM DALY, HOBIJN, AND WILES (2012)}

Daly, Hobijn, and Wiles (2012) present a detailed decomposition of aggregate wage adjustment during the 2007-09 recession and its aftermath along the lines presented in equation (1). They focus on the decomposition of the changes in the aggregate median wage growth of full-time workers. The focus on the wage changes of full-time workers as opposed to the wages of all employed workers allows them to explicitly consider the contribution of part-time workers to the composition effects (3) and (4) described in equation (1), in addition to the contributions of the unemployed or workers out of the labor force. Such effects might be especially important in the aftermath of the 2007-09 recession. First, involuntary part-time employment in the aftermath of 2007-09 was higher than during previous economic recoveries and thus has been one of the topics at the center of the policy discussions regarding labor market resource underutilization. Second, involuntary part-time workers typically receive lower wages than full-time employed workers even after controlling for observable characteristics and broad occupational and industry categories (see, for example, Canon et al. 2015). In addition, Daly, Hobijn, and Wiles (2012) use a novel continuousdistribution version of the shift-share analysis presented in equation (1) to decompose the growth in the aggregate median wage into the changes in individual components versus the growth in aggregate average wage. ${ }^{5}$ As noted in Daly, Hobijn, and Wiles (2012), as opposed to the average wage, median is not affected by fluctuations in overtime, overtime pay, or trends in the average work week for full-time workers.

Daly, Hobijn, and Wiles (2012) use the Current Population Survey (CPS) microdata, 1980-2011, and construct median usual weekly earnings (MWE) of full-time wage and salary workers. The Bureau of Labor Statistics (BLS) publishes MWE of full-time wage and salary

\footnotetext{
${ }^{5}$ The intuition behind the Daly, Hobijn, and Wiles (2012) decomposition is similar to the intuition described by equation (1). The decomposition functions like a shiftshare analysis but works with distribution functions rather than means. An interested reader is referred to the original article for the exact expressions.
} 
workers on a quarterly basis, and it is the only wage series for which the underlying microdata are publicly available. ${ }^{6}$ The microdata for the MWE come from the CPS outgoing rotation groups files (i.e., the data collected from the individuals in their fourth or eighth month of the CPS interview). As such, the published four-quarter aggregate wage growth series is calculated from wages of workers in their fourth or eighth month of the CPS interview in period $t$ and wages of workers who are in their fourth or eighth month of the CPS interview in period $t-1$, i.e., two different samples of workers. Instead, Daly, Hobijn, and Wiles construct the matched MWE from the sample of individuals who are present in both periods - in their interview month eight in period $t$ and in their interview month four in period $t-1$. Such an approach allows linking the changes in aggregate wage growth to the changes in its components, sidestepping the questions of individuals being in and out of the survey due to the survey design. ${ }^{7}$

Daly, Hobijn, and Wiles (2012) observe that workers employed full time in both periods account for, on average, about 90 percent of all full-time wage earners. Consequently, these workers' wages are likely to drive most of the movements in aggregate wages. In contrast, workers exiting from (entering into) full-time employment make up only a small share of overall wage earners. For example, those exiting from fulltime employment to unemployment and entering from unemployment to full-time employment make up only 2.7 percent and 2.6 percent, respectively. However, the flows into and out of full-time employment are typically drawn from below the median wage computed across all employed workers and thus can generate a quantitative impact on the aggregate median wage. For example, 72.8 percent of those who enter from unemployment and 80 percent of those who enter from part-time employment or out of the labor force enter at or below the median wage.

Daly, Hobijn, and Wiles (2012) find that the wage growth effect is strongly procyclical (the coefficient on unemployment is -0.222) and accounts for the majority of the variance of real wage growth over time (91.2 percent). In contrast, the composition effect is countercyclical (the coefficient on unemployment is 0.110 ). Consequently, real median wage growth is procyclical but not in a statistically significant sense

\footnotetext{
${ }^{6}$ To understand the compatibility of the aggregate wage series from the CPS to other widely used series, Daly, Hobijn, and Wiles (2012) show that the MWE compares well with average hourly earnings of production and non-supervisory workers in the private sector, compensation per hour in the nonfarm business sector, and the employment cost index. In particular, the MWE exhibits similar coincident movements with these series, and the correlation with the other series is at least 0.60 .

${ }^{7}$ The correlation between matched MWE and MWE is 0.79 .
} 
(the coefficient on unemployment is -0.112). The authors find that the relative importance of the wage growth effect and the composition effect varies considerably over the business cycle. In downturns, the composition effect rises in importance, offsetting more than half of the procyclicality of the wage growth effect.

Examining the effects of job stayers and job changers separately, Daly, Hobijn, and Wiles (2012) find that the effect of workers who change jobs on the aggregate wage is larger than the effect of workers who remain in the same job from period to period. When labor markets are tight, the job changers' effect is amplified by an increase in the share of the job changers and an increase in the fraction of them moving from below to above the median wage. In labor market downturns, the effects of job changers and job stayers converge as both the share of job changers falls and their relative earnings gains subside.

Interestingly, the unemployment margin is relatively unimportant for the variance and cyclicality of aggregate median full-time wage growth. The net composition effect of unemployment is a sum of the composition effect of workers who transition from employment to unemployment and the composition effect of workers who transition from unemployment to employment. Daly, Hobijn, and Wiles (2012) note the "unemployment penalty," whereby the unemployed workers are typically re-employed at even lower wages than their pre-unemployment wage (due to loss of human capital or some other effects). If the shares of those who enter and exit employment from/to unemployment are similar, the effect of the unemployment component on the aggregate wage is negative. However, because the share of exits from full-time employment to unemployment increases in contractions, the negative effect is somewhat counteracted during downturns. Consequently, the authors find that the net composition effect of unemployment on aggregate wage change is small, negative, and only weakly countercyclical.

Daly, Hobijn, and Wiles (2012) find that much of the composition effect comes through the part-time employment margin. The magnitude of the part-time and self-employment effect relative to other margins owes to the fact that a larger fraction of flows into and out of part time occur below the aggregate medium wage. In contrast to the unemployment margin, the part-time effect does not have offsetting components: In downturns, the share of exits from full time to part time rises and there is little change in the earnings difference between entrants and exits between full-time employment and part-time employment.

Finally, the Daly, Hobijn, and Wiles (2012) results demonstrate that the combined wage growth effect of job changers and job stayers in the aftermath of the 2007-09 recession is lower than after the 
previous downturns. In addition, there has been a larger than usual countercyclical contribution of the composition effect. Much of the countercyclical contribution of the composition effect after 2010 is due to part-time employment (Daly, Hobijn, and Wiles 2012, Figure 7).

\section{ADDITIONAL EVIDENCE ON CHANGES OF WAGES OF JOB STAYERS}

A series of recent articles provides evidence on the change of wages of job stayers. These studies focus on nominal wage rigidities; nevertheless, it is instructive to review the main evidence and the accompanying arguments.

Daly and Hobijn (2015) argue that downward nominal wage rigidity is an explanation for the lack of movement in the opposite direction of wages and unemployment during the 2007-09 downturn and the subsequent recovery. That is, the aggregate wage did not adjust downward during the 2007-09 recession due to nominal wages being more rigid than during previous downturns combined with low inflation. Consequently, they argue that wage growth has not picked up during the economic recovery because firms need to work off a stockpile of pent-up wage cuts.

In contrast, Elsby, Shin, and Solon (2014) argue that while the data show downward nominal wage rigidities, the slight increase in the rigidities during the 2007-09 recession is a part of a pre-existing trend. Similar to Daly, Hobijn, and Lucking (2012), Elsby, Shin, and Solon (2014) note a possible role for the low inflationary environment in the reduced procyclicality of real wages during the 2007-09 recession. However, Elsby, Shin, and Solon (2014) emphasize that wages of job stayers do not play a direct allocative role for employment. Below, we review these two studies in some more detail. Then we provide a brief description of recent evidence on countercyclicality of work effort of job stayers that might render the effective wage of job stayers procyclical even though the actual paid wage does not change over the business cycle.

\section{Downward Nominal Wage Rigidities}

Direct evidence of nominal wage rigidities is presented in Daly, Hobijn, and Lucking (2012). They use the CPS microdata from 1980 to 2011 (hourly or salaried workers who did not change jobs from year to year) and show that nominal wage rigidity appears to increase during recessions and lag during recovery. During the 2007-09 downturn, the share of workers who report no nominal wage change increased 
from 11.2 percent to 16 percent, the highest level observed in any period starting from 1980. Nominal wage rigidities during 2007-09 were prevalent among all educational groups, while during the 1990-91 recession, the higher-educated group (college) did not experience an increase in nominal wage rigidity. The finance, construction, and manufacturing industries experienced the run-up in nominal wage rigidity. Daly, Hobijn, and Lucking (2012) conclude that a somewhat higher rate of inflation would grease the wheels of the labor market by allowing real wages to fall. ${ }^{8}$

Daly and Hobijn (2015) argue that wage growth during the 2007-09 recovery is slow because many firms were unable to reduce wages during the recession and they must now work off a stockpile of pent-up wage cuts. To support the argument, using cross-industry data, they show that industries that were least able to cut wages during the downturn and therefore accrued the most pent-up cuts have experienced relatively slower wage growth during the recovery. ${ }^{9}$

\section{Evidence against Unusually High Nominal Wage Rigidities During the 2007-09 Recession}

Elsby, Shin, and Solon (2014) use a different CPS subsample and a slightly different data treatment than the one used in Daly, Hobijn, and Lucking (2012) and argue that the nominal wage rigidities were not unusually high during the 2007-09 recession and that the slight increase is part of a long-run trend.

Using tenure supplements to the CPS, 1979-2012, Elsby, Shin, and Solon (2014) separately examine nominal wage changes for hourly and non-hourly workers; for non-hourly workers, they use usual weekly earnings instead of constructing the hourly wage by dividing weekly earnings by weekly hours as in Daly, Hobijn, and Lucking (2012).

\footnotetext{
${ }^{8}$ The argument is based on Akerlof, Dickens, and Perry (1996).

${ }^{9}$ The discussion of the relationship between wage inflation and price inflation is beyond the scope of this review. An interested reader is referred to, for example, Daly and Hobijn (2014), who argue that nominal wage rigidity affected the aggregate relationship between the unemployment rate and wage growth during the past three recessions and recoveries and has been especially pronounced during and after the 2007-09 recession. In particular, they present a model of monetary policy with downward nominal rigidities and show that both the slope and curvature of the Phillips curve depend on the level of inflation and the extent of downward nominal wage rigidities. They show that downward wage rigidity results in the "bending" of the Phillips curve whereby the wage growth during a recovery is lower than it is at the same level of the unemployment rate when unemployment is rising, i.e., during the downturn.
} 
Using the real wage levels, Elsby, Shin, and Solon (2014) find that wages are procyclical. ${ }^{10}$ However, during the 2007-09 recession, men's real wages did not fall, while women's real wages adjusted downward. Using data on year-to-year nominal wage changes of job stayers, they report observing "both a substantial minority of workers reporting the same nominal wage in adjacent years (suggesting nominal wage stickiness), but also a substantial minority reporting nominal wage cuts (suggesting nominal wage flexibility). In addition, recent data spanning the Great Recession suggest only a modest rise in the incidence of nominal wage freezes. ${ }^{11}$ The authors conclude that wages are nominally rigid, and that there is an upward trend in nominal wage rigidity.

Similar to Daly, Hobijn, and Lucking (2012), Elsby, Shin, and Solon (2014) note a possible role for the inflationary environment in reducing the procyclicality of men's real wages during the 2007-09 recession. In particular, they write that "[a]t the outset of the recession of the early 1980s, inflation was unusually high, and employers could reduce real wages substantially even while granting nominal wage increases. This was still somewhat true in the recession of the early 1990s, when annual inflation was about 4\%. But during the Great Recession, especially in 2009 , the inflation rate was lower, and substantial real wage cuts would have required nominal wage cuts."

\section{Countercyclical Work Effort}

Additional evidence on the behavior of wages of workers who do not change jobs comes from the recent evidence on countercyclical work effort. If employed workers exert higher effort in recessions, then even if their wage does not change from period to period, the workers' effective wage is lower because they are paid less for a unit of output. Under such a scenario, even though actual wages of job stayers do not change, the effective wages decrease in downturns and increase during recoveries. ${ }^{12}$

\footnotetext{
${ }^{10}$ Elsby, Shin, and Solon (2014) find that regression-adjusted analysis or accounting for unobserved heterogeneity reveals more procyclicality.

${ }^{11}$ Elsby, Shin, and Solon (2014) state that the documented patterns are consistent with those documented by Daly, Hobijn, and Lucking (2012) with two differences: "Daly et al. (2012) divide reported weekly earnings by reported weekly hours to get their nominal wage measure for non-hourly workers. As expected, this leads to considerably smaller spikes at zero nominal wage change. Second, for hourly workers, Daly et al. estimate a substantial dip in the frequency of zero nominal wage change in the years preceding the Great Recession. In contrast, our estimates in Table 5 do not show a drop-off after 2003-04."

${ }^{12}$ See Bils, Chang, and Kim (2013) on how rigid wages of job stayers can amplify the job creation over the business cycle if work effort varies.
} 
The argument about the countercyclicality of work effort is related to a large earlier literature on "efficiency wages" whereby high unemployment induces higher work effort of the employed workers and thus firms do not lower wages of incumbent workers during recessions (Stiglitz 1974). The earlier evidence on efficiency wages is primarily nondirect. Direct evidence on the cyclicality of effective wages is scarce due to the lack of measures of individual workers' output. The exception is Anger (2011), who finds that effective wages are more procyclical than actual wages using German data.

A recent direct piece of evidence of higher worker effort in recessions comes from Lazear, Shaw, and Stanton (2013). Using data spanning June 2006 to May 2010 on individual worker productivity from a large firm, they find evidence that increased productivity during the downturn was mostly due to increases in workers' effort rather than the improved composition of the workforce. That is, firms get more effort from fewer workers, i.e., "making do with less."

The literature on "making do with less" during recessions appears to contradict the earlier literature on labor hoarding (Oi 1962), whereby firms resist firing workers during downturns and instead keep partially or entirely idle workers on their payrolls. To the extent that there have been trend-related decreases in the costs of hiring and training (for example, due to faster depreciation of skills during non-activity) so that labor hoarding has become less prevalent, higher effort during recession can rationalize the increased incidence of downward nominal or real wage rigidity.

\section{RECENT EVIDENCE ON WAGES OF JOB-TO-JOB CHANGERS}

Direct evidence on wages of job changers is presented by Mustre-delRio (2014). Using data on nominal wages of hourly workers in the private sector from the Survey of Income and Program Participation, Mustre-del-Rio constructs the series of monthly wage growth for job switchers (without an intervening spell of joblessness). During 19982012 , the contemporaneous correlation of wage growth of job switchers with quits (from the Job Openings and Labor Turnover Survey) is 0.50. The correlation increases to 0.73 in the post-2007 period, suggesting an even stronger relationship between wage changes of job switchers and quits.

A similar conclusion is derived from the Automatic Data Processing's Workforce Volatility Index. Mustre-del-Rio (2014) finds that job changers' wage growth rose from 4.3 percent per quarter in Q1:2013 to 5.6 percent in Q3:2014. Job changers in leisure and hospitality reached 
an average wage growth of 7.7 percent, switchers in professional and business services reached 6.8 percent, switchers in the education and health sector observed gains of 3.9 percent, and switchers in the manufacturing sector reached 4.2 percent.

How can one reconcile evidence presented by Mustre-del-Rio (2014) that the correlation between wages of job switchers and job quits is even higher after 2007 than it was historically with evidence from Daly, Hobijn, and Wiles (2012) that job changers' wage growth contributed relatively less to the aggregate wage growth during the recovery from the 2007-09 recession? As noted by others, during the recovery from the 2007-09 recession, job-to-job transitions failed to pick up at their historical pace. Higher pay for the same job elsewhere or better jobs available elsewhere enhance the growth of job changers' wages. But if there are no better jobs available, there are no quits. Moscarini and Postel-Vinay (2014) argue that the job ladder "failed" after the 200709 recession. They provide evidence that job-to-job quits collapsed, especially toward large, high-paying employers. Moscarini and PostelVinay argue that new jobs at small employers, the traditional first step of the ladder out of unemployment, vanished, in part because large employers stopped poaching and did not create room for hiring at the bottom. Section 6 reviews additional studies on the types of jobs created during the recovery from the 2007-09 recession, but the evidence is mixed.

\section{WAGES OF HIRES FROM NONEMPLOYMENT}

Recent evidence on wages of workers who transition from nonemployment to employment comes from the studies of wages of recent college graduates. Hobijn and Bengali (2014) argue that the median starting wages of recent college graduates declined to a greater degree than the wages of all full-time workers and that this effect cannot be attributed to the composition of jobs in which the recent graduates are employed. They interpret the evidence as support for the hypothesis of a relatively weak recovery.

In particular, Hobijn and Bengali argue that median nominal wages of recent college graduates (21-25-year-old workers with college degrees; not necessarily newly hired) have not kept pace with median earnings for all workers over the past six years. The wage gap in the current recovery is substantially larger and has lasted longer than the previous recovery.

Hobijn and Bengali then examine whether these developments are due to a composition effect. They present evidence that the distribution

of recent college graduates across occupations has roughly remained the 
same across 2007, 2011, and 2014, while the cumulative nominal wage growth of the graduates between 2007 and 2014 has lagged that of all full-time workers. Based on this evidence, Hobijn and Bengali argue that the larger gap between wages of all full-time workers and the wages of recent graduates represents slow growth in starting salaries for graduates rather than a shift in types of jobs.

Abel, Deitz, and Su (2014) analyze the types of jobs held by recent college graduates in greater detail. They argue that recent graduates are typically "underemployed," i.e., working in jobs that typically do not require a bachelor's degree, ${ }^{13}$ and find that this phenomenon is not specific to the 2007-09 recession as graduates always have a harder time finding well-paid jobs during recessions (Kahn 2010). Abel, Deitz, and $\mathrm{Su}$ (2014), however, find that the quality of the jobs held by the underemployed graduates has declined after the 2007-09 recession to a greater degree than in the past. Consequently, Abel, Deitz, and Su (2014) suggest that low wages of new college graduates are likely due to a composition effect of the types of jobs in which they are employed.

Abel, Deitz, and Su (2014) define a college graduate as underemployed if the occupation she is working in requires a bachelor's degree less than 50 percent of the time, as defined by $\mathrm{O}^{*} \mathrm{NET}$ Education and Training Questionnaire. ${ }^{14}$ The underemployment rate is then the ratio of the number of underemployed college graduates to all employed college graduates. They find that younger college graduates are always more underemployed than older college graduates; however, they were underemployed to a larger degree during the 2007-09 recession. The authors speculate that while there appears to be a cyclical component to underemployment among recent college graduates, the broader Vshaped pattern in the underemployment rate over the past two decades is also consistent with new research arguing that there has been a reversal in the demand for cognitive skills since $2000 .{ }^{15}$

\footnotetext{
${ }^{13}$ Their definition of recent college graduates is slightly different from the one by Hobijn and Bengali (2014) as they include 22-27-year-old, not-in-school workers.

${ }_{14}$ They use the answer to the question "If someone were being hired to perform this job, indicate the level of education that would be required?" and consider college education to be a requirement for a given occupation if at least 50 percent of the respondents working in that occupation indicated that a bachelor's degree is necessary to perform the job.

${ }^{15}$ Abel, Deitz, and Su (2014) write, "[a]ccording to this research, businesses ramped up their hiring of college-educated workers in an effort to adapt to the technological changes occurring during the 1980s and 1990s. However, as the information technology revolution reached maturity, demand for cognitive skill fell accordingly. As a result, during the first decade of the 2000s, many college graduates were forced to move down the occupational hierarchy to take jobs typically performed by lower-skilled workers. From this perspective, the relatively low underemployment rates among recent college graduates at the peak of the technology boom around 2000 may in fact be an outlier, while the recent rise in underemployment represents a return to more typical conditions."
} 
Delving deeper, the authors show that among the underemployed recent college graduates, the share of those with well-paid non-college jobs is decreasing while the share of those with low-paid non-college jobs is increasing. The authors show that these developments have been taking place since 2001 .

Importantly, Abel, Deitz, and Su (2014) show that unemployment and underemployment differ markedly across majors. Specifically, majors providing technical training (quantitative and analytical skills) had the highest shares of graduates working in jobs that require a degree (engineering and math and computers majors). In addition, education and health majors also had high shares of workers employed in jobs that require a college degree, likely reflecting the growth of these sectors in recent years.

\section{TYPES OF JOBS}

Mester and Sen (2013) examine employment growth, distinguishing between qualities of jobs. In particular, they examine employment growth within higher-than-average and lower-than-average wage industries during 1990-2012. They find that in the 1991 and 2001 recessions, when employment begins to grow in a recovery, the first jobs added are typically in industries that are relatively low-paying, while higherpaying jobs are added later as the economy and employment continue to expand. However, after the 2007-09 recession, the story is differentinstead of losing higher-paying jobs at a faster pace than lower-paying jobs during the recession and recovering lower-paying jobs more quickly at the start of the recovery, higher-paying jobs were cut less sharply during the 2007-09 recession and have been added at the same or a faster pace than lower-paying jobs during the recovery.

Mester and Sen note, however, that the analysis is not without caveats. Their classification of industries is not fixed through the sample period. Instead, for each month, they classify industries into higherpaying and lower-paying according to whether their average hourly earnings are above or below, respectively, the national average for all private industries in that month. Consequently, some industries switch from one category to another during the sample period. Specifically, Mester and Sen note that, in 2006, manufacturing switched from being a high-paying industry to a low-paying industry. Repeating that analysis and classifying manufacturing as a high-paying industry after 2006, Mester and Sen find that the pattern from the previous recessions persists into the 2007-09 one - employment growth in high-paying jobs picks up later in the recovery as compared to employment growth in 
low-paying jobs. As such, evidence on the changes in the quality of jobs after the 2007-09 recession is mixed.

\section{CONCLUSIONS}

The review of the literature above reveals that the aggregate wage growth in the aftermath of the 2007-09 recession is low because of the relatively low contribution of the typically procyclical wage growth of job switchers and because of the relatively large contribution of the typically countercyclical composition effect associated with transitions from part-time to full-time employment (Daly, Hobijn, and Wiles 2012). Despite the fact that the overall contribution of job switchers to aggregate wage growth is relatively low in this recovery, the wage gains of workers who do switch jobs are high (Mustre-del-Rio 2014). The issue could thus be a lack of high-wage job opportunities (Moscarini and Postel-Vinay 2014). Such a development may be structural. ${ }^{16}$

\section{REFERENCES}

Abel, Jaison R., Richard Deitz, and Yaqin Su. 2014. "Are Recent College Graduates Finding Good Jobs?" Federal Reserve Bank of New York Current Issues in Economics and Finance 20 (1): 1-8.

Akerlof, George A., William T. Dickens, and George L. Perry. 1996. "The Macroeconomics of Low Inflation." Brookings Papers on Economic Activity 27 (1): 1-76.

Anger, Silke. 2011. "The Cyclicality of Effective Wages within Employer-Employee Matches in a Rigid Labor Market." Labour Economics 18 (December): 786-97.

Autor, David. 2010. "The Polarization of Job Opportunities in the U.S. Labor Market. Implications for Employment and Earnings." Available at http://economics.mit.edu/files/5554.

Barro, Robert J. 1980. "Discussion of Robert E. Hall's 'Labor Supply and Aggregate Fluctuations." Carnegie-Rochester Conference Series on Public Policy 12 (January): 35-8.

\footnotetext{
${ }^{16}$ See, for example, Autor (2010), Jaimovich and Siu (2012), and other works on job polarization.
} 
Barrow, Lisa, and Jason Faberman. 2015. "Wage Growth, Inflation and the Labor Share." Federal Reserve Bank of Chicago Chicago Fed Letter 349 (2015): 1-4.

Basu, Susanto, and Christopher L. House. 2015. "Challenges for New Keynesian Models with Sticky Wages." Available at https://bfi.uchicago.edu/sites/default/files/research/Chicago_ Handbook_Basu_House.pdf.

Bils, Mark J. 1985. "Real Wages over the Business Cycle: Evidence from Panel Data." Journal of Political Economy 93 (August): 666-89.

Bils, Mark, Yongsung Chang, and Sun-Bin Kim. 2013. "How Sticky Wages In Existing Jobs Can Affect Hiring." University of Rochester Working Paper.

Canon, Maria E., Marianna Kudlyak, Guannan Luo, and Marisa Reed. 2015. "Flows To and From Working Part Time for Economic Reasons and the Labor Market Aggregates in the Aftermath of the 2007-09 Recession." Federal Reserve Bank of Richmond Economic Quarterly 100 (Second Quarter): 87-111.

Daly, Mary C., and Bart Hobijn. 2014. "Downward Nominal Wage Rigidities Bend the Phillips Curve." Federal Reserve Bank of San Francisco Working Paper 2013-08.

Daly, Mary C., and Bart Hobijn. 2015. "Why Is Wage Growth So Slow?" Federal Reserve Bank of San Francisco Economic Letter 2015-01 (January 5).

Daly, Mary C., Bart Hobijn, and Brian Lucking. 2012. "Why has Wage Growth Stayed Strong?" Federal Reserve Bank of San Francisco Economic Letter 2012-10 (April 2).

Daly, Mary C., Bart Hobijn, and Theodore S. Wiles. 2012. "Dissecting Aggregate Real Wage Fluctuations: Individual Wage Growth and the Composition Effect." Federal Reserve Bank of San Francisco Working Paper 2011-23.

Davis, Steven J., and John Haltiwanger. 2014. "Labor Market Fluidity and Economic Performance." Working Paper 20479. Cambridge, Mass.: National Bureau of Economic Research. (September).

Elsby, Michael W. L., Donggyun Shin, and Gary Solon. 2014. "Wage Adjustment in the Great Recession and Other Downturns: Evidence from the United States and Great Britain." Mimeo, University of Edinburg. 
Foster, Lucia, John Haltiwanger, and C. J. Krizan. 2001. "Aggregate Productivity Growth: Lessons from Microeconomic Evidence." In New Developments in Productivity Analysis, edited by Edward Dean, Michael Harper, and Charles Hulten. Chicago: University of Chicago Press, 303-72.

Haefke, Christian, Marcus Sonntag, and Thijs van Rens. 2013. "Wage Rigidity and Job Creation." Journal of Monetary Economics 60 (November): 887-99.

Hobijn, Bart, and Leila Bengali. 2014. "The Wage Growth Gap for Recent College Grads." Federal Reserve Bank of San Francisco Economic Letter 2014-22 (July 21).

Jaimovich, Nir, and Henry E. Siu. 2012. "The Trend is the Cycle: Job Polarization and Jobless Recoveries." Working Paper 18334. Cambridge, Mass.: National Bureau of Economic Research. (August).

Kahn, Lisa B. 2010. "The Long-Term Labor Market Consequences of Graduating from College in a Bad Economy." Labour Economics 17 (April): 303-16.

Kudlyak, Marianna. 2009. "Are Wages Rigid Over the Business Cycle?" Federal Reserve Bank of Richmond Economic Quarterly 96 (Second Quarter): 179-99.

Kudlyak, Marianna. 2014. "The Cyclicality of the User Cost of Labor." Journal of Monetary Economics 68 (November): 53-67.

Lazear, Edward P., Kathryn L. Shaw, and Christopher Stanton. 2013. "Making Do With Less: Working Harder During Recessions." Working Paper 19328. Cambridge, Mass.: National Bureau of Economic Research. (August).

Martins, Pedro S., Gary Solon, and Jonathan P. Thomas. 2012. "Measuring What Employers Do about Entry Wages over the Business Cycle: A New Approach." American Economic Journal: Macroeconomics 4 (4): 36-55.

McLaughlin, Kenneth J., and Mark Bils. 2001. "Interindustry Mobility and the Cyclical Upgrading of Labor." Journal of Labor Economics 19 (January): 94-135.

Mester, Loretta J., and Elif Sen. 2013. "Has Job Quality Been 'Job One' in the Economic Recovery?" Federal Reserve Bank of Philadelphia Research Rap, 1-18. (August).

Moscarini, Giuseppe, and Fabien Postel-Vinay. 2014. "Did the Job Ladder Fail after the Great Recession?" Working Paper. 
Mustre-del-Rio, Jose. 2014. "Following the Leaders: Wage Growth of Job Switchers." Federal Reserve Bank of Kansas City Macro Bulletin 2014 (December): 1-2.

Oi, Walter Y. 1962. "Labor as a Quasi-Fixed Factor." Journal of Political Economy 70 (December): 538-55.

Pissarides, Christopher A. 2009. "The Unemployment Volatility Puzzle: Is Wage Stickiness the Answer?" Econometrica 77 (September): 1,339-69.

Solon, Gary, Robert Barsky, and Jonathan A. Parker. 1994. "Measuring the Cyclicality of Real Wages: How Important is Composition Bias." The Quarterly Journal of Economics 109 (February): 1-25.

Stiglitz, Joseph E. 1974. "Alternative Theories of Wage Determination and Unemployment in LDC's: The Labor Turnover Model." The Quarterly Journal of Economics 88 (May): 194-227. 